\title{
EDTA-INDUCED CHANGES OF MICROELEMENT CONCENTRATION IN CONNECTIVE TISSUE OF BOVINE HIDE
}

\author{
P. SMEJKAL*, OLGA ČELECHOVSKÁ, A. BLAŽEJ*, S. ZIMA
}

*Slovak Technical University, Department of Protein Chemistry, 76582 Otrokovice University of Veterinary Science, Department of Chemistry, Physics and Biochemistry, 61242 Brno

Received Fuly 2, 1982

\begin{abstract}
Smejkal P., Čelechovská Olga, Blažej A., Zima S.: EDTA-Induced Changes of Microelement Concentration in Connective Tissue of Bovine Hide. Acta vet. Brno, 52, 1983: $145-150$.

The connective tissue of skin contains microelements which are involved in the biopolymer interactions. Calcium is one of the essential elements playing an important role in the stabilization of connective tissue. The presence of ethylenediaminetetraacetic acid (EDTA) in the system seriously interferes with the calcium mediated interactions, this being a consequence of high values of the complex stability constants of EDTA with regard to calcium. In this way, some proteins may be released from the connective tissue. The changes of calcium concentration, as well as those of other elements, induced by the presence of EDTA were followed by atomic absorption spectrophotometry and are discussed.
\end{abstract}

Collagen, microelements, atomic absorption, spectrophotometry.

Corium of the bovine skin represents form the viewpoint of proteins a multicomponent system. Approximately $30 \%$ of fresh skin mass consists of proteins (Adam and Deyl 1978). Collagen is a dominant component of the connective tissue. In general, its quantity and sterical orientation conform with its function in the tissue. Until now, six basic collagen types of different primary structure have been identified in various tissues. The metabolic activity of mesodermal somatic cells results in high molecular products which further interact with biopolymers and low molecular compounds thus forming the structures generally denoted as intercellular mass (Steven 1965). The latter is predominantly composed of glycoproteins and proteoglycans. Glycoproteins are biopolymers containing saccharides attached by covalent bonds. Proteoglycans contain in their polypeptidic chain glycosaminoglycans (formerly denoted as acid mucopolysaccharides) bonded via hydroxyl groups at the point of hydroxylaminoacids. Among glycoproteins, proteoglycans and collagen there exist non-polar interactions. Moreover, the existence of interactions mediated by calcium is also assumed (S teven 1967). The calcium cross-links may be destroyed by chelating agents (Steven 1967; S mejkal and Blažej 1971). Mathews (1965) suggested that the metals present in the skin connective tissue may exhibit a stabilizing effect upon collagen and interfibrillar matrix.

Ethylenediaminetetraacetic acid (EDTA) and its salts belong to important chelating agents. Its complexes have high stability constants, particularly for calcium, magnesium and iron (log $\mathrm{K}_{\mathrm{Ca}^{2}}{ }^{2}=10.59, \log \mathrm{K}_{\mathrm{Mg}^{2}+}{ }^{2}=8.69, \log \mathrm{K}_{\mathrm{Fe}^{2+}}{ }^{2+}=14.5-\mathrm{Martel}$ and Calvin 1956).

Herring and Kent (1963) used EDTA for the extraction of bones. Steven (1967) employed EDTA for the removal of interfibrillar matrix from the tendons and skin in rat. EDTA was also applied during the isolation of elastin from tissues (Grant and Steven 1971). It was also suggested to make use of EDTA to remove interfibrillar matrix when making cut gut (Griset and Riessman $n$ 1970).

Calcium represents one of the most important bivalent element in mammalian organism. The highest concentrations of this element are in the skeleton where, together with collagen, they form the supporting system. This amount in adult man corresponds to ca $0.18 \%$ of his mass. 
In human skin the average concentration is about $10 \mathrm{mg} / \mathrm{kg}$. Copper is another metal whose presence is essential for the process of collagen stabilization. It is a co-factor of lysyloxidasis which oxidizes lysine to monoaldehyde of alpha-aminoadipic acid. The latter participates in the formation of cross-links in vivo (Steven 1965 and Adam et al. 1970).

The determination of metals in skin connective tissue has been carried out using the spectrographical analysis. Casel and Kanagy (1949) analyzed the dehydrated bovine skin and found the following metal concentrations: $50 \mu \mathrm{g} / \mathrm{g} \mathrm{Cu}$ and $\mathrm{Fe}, 20 \mu \mathrm{g} / \mathrm{g} \mathrm{Pb}$ and $\mathrm{Ca}$ and $10 \mu \mathrm{g} / \mathrm{g}$ Sn and Cr.

McMullen and Deasy (1974) have also analyzed bovine skin by the spectrographic method and qualitatively determined the presence of $\mathrm{Na}, \mathrm{Ca}, \mathrm{Co}, \mathrm{Cd}$, and $\mathrm{Mn}$. The method of electron probe has also been employed for the determination of microelements in skin (Griset and Riessmann 1970). The so far published papers lack the details concerning the preparation of samples prior to microelement determination. For this reason the results are difficult to compare.

\section{Materials and Methods}

The influence of EDTA $(0.1 \mathrm{~mol} / \mathrm{l})$ upon the corium of bovine skin was followed at $\mathrm{pH} 7.0$. Fresh skin from the slaughterhouse was shortly washed in ice-cold deionized water. Subcutaneous tissue and epidermis were mechanically removed using a scalpel. The corium was cut to $1 \times 1 \mathrm{~cm}$ pieces. The $\mathrm{pH}$ value of $1.0 \mathrm{~mol} / \mathrm{l}$ EDTA was set to 7.0 by the solution of $\mathrm{NaOH}$ of the same concentration. This EDTA solution was then diluted to $0.1 \mathrm{~mol} / 1$ and used for the treatment. The skin cuttings were placed into polyethylene flasks and shaken at $4{ }^{\circ} \mathrm{C}$ with 10 fold excess of EDTA solution for $3 \times 24$ hours. The same treatment was carried out simultaneously with deionized water. Both the corium and solution samples were analyzed by atomic absorption spectrophotometry (AAS).

The process of sample preparation prior to the AAS analysis significantly influences the final results of analysis (Gorsuch 1970 and Kirkbright and Sargent 1974). In order to avoid the element loss during dry-ashing procedure we used a wet oxidation method of corium sample preparation. $10 \mathrm{~g}$ of corium (analyzed for the dry matter contents by dehydration) was treated with $3 \mathrm{ml}$ of concentrated sulphuric acid (analytical grade) and after 3 hours, $15 \mathrm{ml}$ of concentrated nitric acid (analytical grade) was added. The vessel was then heated under reflux on a sand bath for 3 hours. After this time the contents were transferred quantitatively into a $100 \mathrm{ml}$ volumetric flask using deionized water and the solution was made up to the mark. The blank experiment was also carried out in order to determine the concentration of microelements in EDTA, conc. $\mathrm{H}_{2} \mathrm{SO}_{4}$ and conc. $\mathrm{HNO}_{3}$. All glass vessels used for this work were immersed into $10 \%$ solution of $\mathrm{HNO}_{3}$ for 24 hours and then well rinsed with deionized water prior to use.

The determination of elements in corium and its extracts was carried out on AA- 6 and AA-1000 VARIAN TECHTRON instruments. Cobalt, chromium, manganese and nickel were determined using the flameless atomization technique by a CRA-90 with the hydrogen background corrector BC-6. Iron, calcium, magnesium, zinc and copper were determined by flame AAS in acetylene-air flame. The background correction was measured by a hydrogen lamp. The calibration curve method and standard additions were employed in both cases. The solutions of BDH Chemicals Ltd. were used as standards. The working conditions of the instrument are presented in Table 1.

Table 1

AAS parameters and temperature programme used for analyses

\begin{tabular}{|c|c|c|c|c|c|c|}
\hline Element & $\begin{array}{c}\text { Wavelength } \\
\mathrm{nm}\end{array}$ & $\begin{array}{l}\text { Slit } \\
\mathrm{nm}\end{array}$ & $\begin{array}{c}\text { Lamp } \\
\text { current } \\
\mathrm{mA}\end{array}$ & Atmosphere & $\underset{{ }^{\circ} \mathrm{C}}{\text { Combion }}$ & $\begin{array}{l}\text { Temperature of } \\
\text { atomization / time/ } \\
\text { heating rate } \\
{ }^{\circ} \mathrm{C} / \mathrm{s} /{ }^{\circ} \mathrm{C} . \mathrm{s}^{-1}\end{array}$ \\
\hline $\begin{array}{l}\mathrm{Mn} \\
\mathrm{Co} \\
\mathrm{Cr} \\
\mathrm{Ni}\end{array}$ & $\begin{array}{l}279.5 \\
240.7 \\
357.9 \\
232.0\end{array}$ & $\begin{array}{l}0.2 \\
0.1 \\
0.5 \\
0.2\end{array}$ & $\begin{array}{l}3 \\
5 \\
5 \\
5\end{array}$ & $\begin{array}{l}\mathrm{N}_{2}-\mathrm{H}_{2} \\
\mathrm{~N}_{2}-\mathrm{H}_{2} \\
\mathrm{~N}_{2}-\mathrm{H}_{2} \\
\mathrm{~N}_{2}-\mathrm{H}_{2}\end{array}$ & $\begin{array}{r}700 \\
500 \\
1100 \\
1200\end{array}$ & $\begin{array}{l}2000 / 2 / 70 \\
2400 / 2 / 600 \\
2400 / 1 / 400 \\
2300 / 2 / 700\end{array}$ \\
\hline $\begin{array}{l}\mathrm{Cu} \\
\mathrm{Fe} \\
\mathrm{Ca} \\
\mathrm{Mg} \\
\mathrm{Zn}\end{array}$ & $\begin{array}{l}324.8 \\
248.3 \\
422.7 \\
285.2 \\
213.9\end{array}$ & $\begin{array}{l}0.2 \\
0.2 \\
0.5 \\
0.5 \\
0.5\end{array}$ & $\begin{array}{l}3 \\
5 \\
8 \\
3 \\
5\end{array}$ & \multicolumn{3}{|c|}{$\begin{array}{l}\text { flame air - acetylene, oxidative } \\
\text { flame air - acetylene, oxidative } \\
\text { flame air - acetylene, oxidative } \\
\text { flame air - acetylene, oxtdative } \\
\text { flame air - acetylene, oxidative }\end{array}$} \\
\hline
\end{tabular}


Element content in corium of bovine hide in $\mu \mathrm{g} / \mathrm{g}$ dry matter

\begin{tabular}{|c|c|c|c|c|c|c|}
\hline \multirow{2}{*}{ Element } & \multicolumn{3}{|c|}{$\begin{array}{l}\text { Concentration in corium after } \\
\text { treatment with water }\end{array}$} & \multicolumn{3}{|c|}{$\begin{array}{l}\text { Concentration in corium after } \\
0.1 \mathrm{~mol} / 1 \mathrm{EDTA} \text { treatment }\end{array}$} \\
\hline & $\begin{array}{c}c \\
\mu \mathrm{g} / \mathrm{g}\end{array}$ & $\stackrel{\mathrm{s}}{\mu \mathrm{g} / \mathrm{g}}$ & $\begin{array}{c}95 \% \text { IS } \\
\because g\end{array}$ & $\begin{array}{c}c \\
\mu \mathrm{g} / \mathrm{g}\end{array}$ & $\stackrel{\mathrm{s}}{\mu \mathrm{g} / \mathrm{g}}$ & $\begin{array}{c}95 \% \text { IS } \\
\mu \mathrm{g} / \mathrm{g}\end{array}$ \\
\hline $\begin{array}{l}\mathrm{Ca} \\
\mathrm{Fe} \\
\mathrm{Zn} \\
\mathrm{Mg} \\
\mathrm{Ni} \\
\mathrm{Cr} \\
\mathrm{Mn} \\
\mathrm{Cu} \\
\mathrm{Co}\end{array}$ & $\begin{array}{r}513.4 \\
27.4 \\
5.5 \\
5.3 \\
1.4 \\
5.3 \\
1.7 \\
1.1 \\
0.0\end{array}$ & $\begin{array}{l}5.8 \\
0.4 \\
0.9 \\
0.2 \\
0.1 \\
9.2 \\
0.1 \\
0.2 \\
.\end{array}$ & $\begin{array}{c}500.5-526.3 \\
26.6-28.2 \\
3.5-7.5 \\
4.9-5.7 \\
1.3-1.5 \\
4.8-5.8 \\
1.6-1.7 \\
0.7-1.5 \\
-\end{array}$ & $\begin{array}{r}<1.0 \\
48.2 \\
3.0 \\
<0.5 \\
1.4 \\
4.7 \\
0.5 \\
0.5 \\
0.0\end{array}$ & $\begin{array}{l}-\overline{9} \\
9.1 \\
0.6 \\
- \\
0.2 \\
0.04 \\
0.07 \\
0.11 \\
-\end{array}$ & $\begin{array}{c}28.2-68.2 \\
1.6-4.4 \\
- \\
0.9-1.9 \\
4.4-5.0 \\
0.44-0.56 \\
0.36-0.74 \\
-\end{array}$ \\
\hline
\end{tabular}

$c$ - average concentration, $s$ - standard deviation

$95 \%$ IS - reliability interral

\section{Results}

Table 2 presents the concentrations of elements in corium after the treatment with water and $0.1 \mathrm{~mol} / 1 \mathrm{EDTA}$, respectively. The greatest differences are seen in the case of calcium and magnesium while in the case of zinc and other elements the differences are less pronounced. Table 3 shows the element concentrations in corium treated with water and EDTA, resp. (values 1,2 ) as well as those found in extracts. The samples for the presented experiments were obtained from three simultaneous extractions. The statistical treatment of results revealed a satisfactory consistence of individual analyses.

\section{Discussion}

The levels of metal elements in bovine corium determined by AAS, employing the solution method of sample preparation, are difficult to reconcile with the results reported by Casel and Kanagy (1949) obtained by spectrography. The comparison is made difficult also due to the absence of details concerning the sample preparation. McMullen and Deasy (1974) published only the qualitative participation of elements in skin.

Out of the bivalent elements the position of calcium is dominant. Its concentration decrease to zero after the EDTA treatment in comparison with initial $513 \mu \mathrm{g} / \mathrm{g}$ of dry matter in bovine corium is a consequence of high stability constant of calcium complex. The overall amount of calcium is 19 times higher than that of iron, which is the second most abundant microelement in the corium of the bovine skin. The higher iron content in the dry matter of bovine skin corium after the extraction with EDTA when compared with the residual amount after the extraction with water is still unaccounted for.

Out of all the elements analyzed, i. e. $\mathrm{Ca}, \mathrm{Fe}, \mathrm{Zn}, \mathrm{Mg}, \mathrm{Ni}, \mathrm{Cr}, \mathrm{Mn}, \mathrm{Cu}$ and $\mathrm{Co}$ only $\mathrm{Ca}(11.6 \mu \mathrm{g} / \mathrm{g})$ and $\mathrm{Mg}(0.65 \mu \mathrm{g} / \mathrm{g})$ were found to be present in water extracts. In extracts effected by EDTA all elements, with the exception of $\mathrm{Cu}$, were found. Cobalt was not found in the corium of bovine skin, this being in discrepancy 
Table 3

Microelement concentration in samples of corium and in extracts

\begin{tabular}{|c|c|c|c|c|c|c|}
\hline Flement & $\begin{array}{c}\text { Sample } \\
\text { No. }\end{array}$ & $\begin{array}{c}\mathrm{c} \\
\mu \mathrm{g} / \mathrm{g} \\
\mu \mathrm{g} / \mathrm{ml}\end{array}$ & $\begin{array}{c}\mathrm{s} \\
\mu \mathrm{g} / \mathrm{g} \\
\mu \mathrm{g} / \mathrm{ml}\end{array}$ & $\begin{array}{l}\mathbf{s}_{\mathbf{r}} \\
\%\end{array}$ & $\underset{\mu \mathrm{g} / \mathrm{g}}{\mathrm{s} \mathrm{p}}$ & $\begin{array}{c}95 \% \text { IS } \\
\mu \mathrm{g} / \mathrm{g} \\
\mu \mathrm{g} / \mathrm{ml}\end{array}$ \\
\hline $\mathrm{Ca}$ & $\begin{array}{l}1 \\
2 \\
3 \\
4\end{array}$ & $\begin{array}{r}513.4 \\
<1.0 \\
11.59 \\
4.15\end{array}$ & $\begin{array}{l}5.79 \\
\overline{0} \\
0.55 \\
0.14\end{array}$ & $\begin{array}{l}1.1 \\
- \\
4.8 \\
3.3\end{array}$ & $\begin{array}{c}3.36 \\
- \\
0.28 \\
0.08\end{array}$ & $\begin{array}{c}500.5-526.3 \\
- \\
10.77-12.41 \\
3.84-4.46\end{array}$ \\
\hline $\mathrm{Fe}$ & $\begin{array}{l}1 \\
2 \\
3 \\
4\end{array}$ & $\begin{array}{l}27.43 \\
48.19 \\
0.0 \\
0.157\end{array}$ & $\begin{array}{c}0.38 \\
9.07 \\
\overline{0} \\
0.01\end{array}$ & $\begin{array}{c}1.4 \\
18.8 \\
-- \\
6.0\end{array}$ & $\begin{array}{l}0.22 \\
5.26 \\
0.006\end{array}$ & $\begin{array}{c}26.60-28.26 \\
28.24-68.14 \\
- \\
0.136-0.178\end{array}$ \\
\hline $\mathrm{Zn}$ & $\begin{array}{l}1 \\
2 \\
3 \\
4\end{array}$ & $\begin{array}{l}5.53 \\
2.96 \\
0.00 \\
0.072\end{array}$ & $\begin{array}{l}0.89 \\
0.62 \\
\overline{0} \\
0.005\end{array}$ & $\begin{array}{c}16.1 \\
20.8 \\
\cdots \\
6.6\end{array}$ & $\begin{array}{l}0.52 \\
0.36 \\
0.003\end{array}$ & $\begin{array}{c}3.57-7.49 \\
1.60-4.42 \\
- \\
0.061-0.083\end{array}$ \\
\hline $\mathrm{Mg}$ & $\begin{array}{l}1 \\
2 \\
3 \\
4\end{array}$ & $\begin{aligned} & 5.28 \\
< & 0.5 \\
& 0.655 \\
& 1.01\end{aligned}$ & $\begin{array}{l}0.19 \\
\overline{0} \\
0.007 \\
0.034\end{array}$ & $\begin{array}{l}3.7 \\
- \\
1.0 \\
3.4\end{array}$ & $\begin{array}{l}0.11 \\
\ldots \\
0.004 \\
0.02\end{array}$ & $\begin{array}{c}4.85-5.71 \\
- \\
0.640-0.670 \\
0.93-1.09\end{array}$ \\
\hline $\mathrm{Cr}$ & $\begin{array}{l}1 \\
2 \\
3 \\
4\end{array}$ & $\begin{array}{l}5.28 \\
4.65 \\
0.0 \\
0.268\end{array}$ & $\begin{array}{l}0.23 \\
0.04 \\
-\overline{-} \\
0.005\end{array}$ & $\begin{array}{l}4.3 \\
0.8 \\
-- \\
1.8\end{array}$ & $\begin{array}{c}0.13 \\
0.03 \\
\ldots \\
0.003\end{array}$ & $\begin{array}{c}4.79-5.77 \\
4.39-4.91 \\
- \\
0.257-0.279\end{array}$ \\
\hline $\mathrm{Mn}$ & $\begin{array}{l}1 \\
2 \\
3 \\
4\end{array}$ & $\begin{array}{l}1.74 \\
0.507 \\
0.004 \\
0.054\end{array}$ & $\begin{array}{l}0.11 \\
0.065 \\
6.10^{-4} \\
0.003\end{array}$ & $\begin{array}{r}6.2 \\
12.8 \\
13.6 \\
5.4\end{array}$ & $\begin{array}{l}0.05 \\
0.025 \\
3.10^{-4} \\
0.002\end{array}$ & $\begin{aligned} & 1.70-1.78 \\
& 0.449-0.565 \\
2.4 & 10^{-3}-5.6 \cdot 10^{-3} \\
& 0.048-0.06\end{aligned}$ \\
\hline $\mathrm{Ni}$ & $\begin{array}{l}1 \\
2\end{array}$ & $\begin{array}{l}1.38 \\
1.41\end{array}$ & $\begin{array}{l}0.058 \\
0.240\end{array}$ & $\begin{array}{r}4.2 \\
14.9\end{array}$ & $\begin{array}{l}0.03 \\
0.14\end{array}$ & $\begin{array}{l}1.25-1.51 \\
0.88-1.94\end{array}$ \\
\hline $\mathrm{Cu}$ & $\begin{array}{l}1 \\
2 \\
3 \\
4\end{array}$ & $\begin{array}{l}1.96 \\
0.456 \\
0.0 \\
0.0\end{array}$ & $\begin{array}{l}0.17 \\
0.108 \\
- \\
-\end{array}$ & $\begin{array}{c}16.5 \\
23.6 \\
- \\
-\end{array}$ & $\begin{array}{c}0.10 \\
0.06 \\
- \\
-\end{array}$ & $\begin{array}{c}0.67-1.45 \\
0.219-0.693 \\
- \\
-\end{array}$ \\
\hline Co & $\begin{array}{l}1 \\
2 \\
3 \\
4\end{array}$ & $\begin{array}{l}0.0 \\
0.0 \\
0.0 \\
0.0\end{array}$ & $\begin{array}{l}\overline{-} \\
\overline{-} \\
\overline{-}\end{array}$ & $\begin{array}{l}- \\
- \\
- \\
-\end{array}$ & $\begin{array}{l}- \\
- \\
\cdots \\
-\end{array}$ & $\begin{array}{l}- \\
\overline{-} \\
-\end{array}$ \\
\hline
\end{tabular}

Sample 1 - corium treated with water

Sample 2 - corium treated with EDTA $(0.1 \mathrm{~mol} / \mathrm{l})$

Sample 3 - extract from sample 1

Sample 4 - extract from sample 2

$c$ - average concentration

$s_{\mathrm{p}}$ - mean standard deviation

s - standard deviation

$\mathbf{s}_{\mathbf{r}}$ - relative standard deviation

$95 \%$ IS - reliability interval

Concentrations in samples 1,2 are in $\mu \mathrm{g}$ per $\mathrm{g}$ of dry matter

Concentrations in samples 3,4 are in $\mu \mathrm{g}$ per $\mathrm{ml}$ of extract

with the results of qualitative analysis published by McMullen and Dasy (1974). The overall balance of elemental distribution in the corium of bovine skin and in the solution after the EDTA treatment could not be done since considerable amounts of EDTA precipitate during the preparation of aqueous solutions. The obtained results have shown pronounced changes in the elemental concentration induced by the action of EDTA upon the corium of bovine skin in vitro. 


\section{Změny v obsahu mikroelementů vaziva hovězí kůže podmíněné působením EDTA}

V systému vaziva kůže jsou obsaženy mikroelementy, které se podílejí na interakcích mezi biopolymery. Významné místo mezi esenciálními prvky z hlediska stabilizace pojiva má vápník. Působením EDTA, která má vysoké konstanty stability komplexu vzhledem $\mathrm{k}$ vápníku, lze porušit interakce zprostředkované vápníkem a některé bílkoviny uvolnit $\mathrm{z}$ pojiva kůže. Jsou diskutovány změny $\mathrm{v}$ obsahu vápníku a dalších prvků $\mathrm{v}$ důsledku působení EDTA na kožní vazivo stanovené pomocí atomové absorpční spektrofotometrie.

Изменения содержания микроэлементов соединительной ткани говяжьей шкуры, обусловленные влиянием этилендиаминотетрауксусной кислоты

В системе соединительной ткани шкуры содержатся микроэлементы, принимающие участие во взаимодействии между биополимерами. Важное место среди эссенциальных әлементов с точки зрения стабилизации соединительной ткани играет кальций. Воздействием этилендиаминотетрауксусной кисэоты, отличающейся высокими константами устойчивости комплекса по отношению к кальцию, можно нарушить взаимодействие посредством калыция и выделить некоторые белки из соединительной ткани кожи. Обсуждаются изменения содержания кальция и других веществ в результате воздействия этилендиаминотетрауксусной кислоты на соединительную ткань кожи, устанавливаемые с помощью атомной абсорбционной спектрофотометрии.

\section{References}

ADAM, M. - DEYL, Z. - ROSMUS, J.: Interaction of collagen with metals in vivo. In: Rozpravy CSAV, 80, 1970: 4-95.

ADAM, M. - DEYL, Z.: Kolagen. In: BLAŽEJ, A. et al.: Struktura a vlastnosti vláknitých bílkovin. Bratislava, SAV 1978, pp. 159-219.

CASEL, J. M. - KANAGY, J. R.: Studies on the purification of collagen. J. Amer. Leather. Chem. Assoc., 44, 1949: 424-441.

GORSUCH, T. T.: The destruction of organic matter. 1. ed. Pergamon Press, Oxford, New York $1970,151 \mathrm{p}$.

GRANT, M. E. - STEVEN, F. S. - JACKSON, D. S.: Carbohydrate content of insoluble elastins prepared from adult bovine and calf ligamentum nuchae and tropoelastin isolated from copper deficient porcine aorta. Biochem. J., 121, 1971: 197-202.

GRISET, W. - RIESSMANN, J. R. - NICHOLS, G.: GFR Patent 1.417368.

HERRING, G. M. - KENT, P. W.: Some studies on mucosubstances of bovine cortical bone. Biochem. J., 89, 1963: 405-413.

KIRKBRIGHT, G. F. - SARGENT, M.: Atomic absorption and fluorescence spectroscopy. 1. ed. Academic Press, London 1974, 798 p.

MARTEL, A. E. - CALVIN, M.: Chemistry of the metal chelate compounds. Prentice-Hall Inc., New York 1956, 475 p.

MATHEWS, M. B.: The interaction of collagen and acid mucopolysaccharides a model for connective tissue. Biochem. J., 96, 1965: 710-716.

McMULLEN, M. A. - DEASY, C.: The effect of some chelating agents on the tensile strength and toughness index of steer hide. J. Amer. Leather Chemist. Assoc., 69, 1974: 251-261.

MUSIL, J.: Glykoproteiny pojiva a jejich vztah $\mathrm{k}$ vápníku. In: Biologicky aktivní látky s obsahem P, Ca, Fe. Mezná 1978, pp. 88-103. 
SMEJKAL, P. - BLAŽEJ, A.: Long term influence of EDTA on hide tissue. In: XIII. Congress IULCS, Wien 1971, pp. 71-78.

SMEJKAL, P. - BLAŽEJ, A.: Studium dlouhodobého účinku EDTA na kožní vazivo. Kožařství, 24, 1974: 270-272.

STEVEN, F. S.: Multiple-stage depolymerisation of collagen fibres. Biochim. biophys. Acta, 97, 1965: $465-472$.

STEVEN, F. S.: Depolymerisation of collagen. Biochim. biophys. Acta, 140, 1967: 522-529. 